ISSN 1980-5918

Fisioter. Mov., Curitiba, v. 29, n. 4, p. 751-756, Oct./Dec. 2016

Licenciado sob uma Licença Creative Commons DOI: http://dx.doi.org/10.1590/1980-5918.029.004.A011

\title{
Lower back pain and level of disability amongst construction workers
}

\author{
Dor lombar e nível de incapacidade funcional \\ em trabalhadores da construção civil
}

\author{
Samya Pinheiro Araújo, Laise Neves Carvalho, Érica Silva Martins*
}

Universidade Ceuma, São Luis, MA, Brazil

\begin{abstract}
Introduction: Lower back pain is a symptom that significantly affects people's lives, especially workers whose professional achievements can be limited by this pain. Objective: Estimate prevalence of lower back pain and describe the levels of disability amongst construction workers. Methods: 84 construction workers participated in this study. Each of them was given three questionnaires. The first questionnaire was aimed at identifying sociodemographic variables such as work and lifestyle habits. The second questionnaire was created by Monnerat and Pereira to measure the intensity of lower back pain. The last questionnaire was created by Roland-Morris to measure functional incapacity. The SPSS 18.0 program was used for data analysis. Lower back pain was described with the Mann Whitney U test using the variables of both labor and time. Furthermore, a correlation between lower back pain intensity and functional incapacity was found by Spearman. Results: A higher prevalence of lower back pain was found (71.4\%) amongst the construction workers especially during laborious activity. Time worked did not affect the prevalence of lower back pain nor did it lead to functional incapacity in workers. Conclusion: Based on all observed data, it was concluded that strenuous labor activity amongst the populace drove lower back pain prevalence.
\end{abstract}

Keywords: Prevalence. Lower Back Pain. Disability. Workers.

*SPA: BS, e-mail: mya.duarte@hotmail.com LNC: MS, e-mail: lanevescarvalho@hotmail.com ESM: MS, e-mail: ericasmt@hotmail.com 
Resumo

Introdução: A dor lombar é um sintoma que afeta de forma significativa a vida das pessoas e principalmente dos trabalhadores que pela influencia da dor acabam apresentando limitações nas realizações das atividades profissionais. Objetivo: Estimar prevalência da dor lombar e descrever o nível de incapacidade funcional em trabalhadores da construção civil. Métodos: Participaram do estudo 84 trabalhadores da construção civil onde foram aplicados três questionários. O primeiro para identificação de variáveis sociodemográficas, laborais e hábitos de vida, o segundo de Monnerat e Pereira para mensurar intensidade da dor lombar e o último de incapacidade funcional de Roland-Morris. Para análise dos dados foi utilizado o programa SPSS 18,0. Para as variáveis dor lombar, incapacidade funcional e tempo de serviço foram utilizados o Mann Whitney, entre intensidade da dor lombar e incapacidade, a correlação de Spearman. Resultados: Foi encontrada uma alta prevalência de dor lombar $(71,4 \%)$ entre os trabalhadores da construção civil sendo mais frequente durante a atividade laboral. 0 tempo de serviço não levou a existência da dor lombar e a dor não acarretou aos trabalhadores incapacidade funcional. Conclusão: A partir dos dados obtidos nessa pesquisa sugere-se que a atividade laboral da população estudada acarretou a alta prevalência de dor lombar.

Palavras-chave: Prevalência. Dor Lombar. Incapacidade. Trabalhadores.

\section{Introduction}

A vast number of individuals in the world are affected by spinal pain (1). Furthermore, the most prevalent form of spinal pain occurs in the lower back (2).

Lower back pain is a debilitating symptom that can potentially limit a person's quality of life, especially workers whose professional achievements can be limited by this pain (3).

Lower back pain stemming from strenuous activity is usually caused by biomechanical tension due to excessive anterior flexions and worsens with heavier weight. Thus, poor or static posture, vibrations, repetitive movements for long durations all contribute to lower back pain (4). The construction industry is a prime example of a career in which lower back pain induced from labor is common. The labor is intensive and demanding, often requiring the lifting of heavy weight which can cause excessive stress and pressure on the vertebrae and intervertebral discs (5).

Construction workers show higher prevalence of lower back pain due to the exhausting nature of their labor. It is important to emphasize that bad work conditions and low education rates also contribute to this prevalence (6).

People who felt this type of pain presented higher fears of it worsening; therefore they avoided making drastic movements. In addition, their work conditions predispose them to functional incapacity causing a negative impact on their quality of life (7).
Beside the impact on their quality of life, this functional incapacity causes numerous labor disorders, which leads them to withdraw from work more often (8). It is the most common labor injury that INSS deals with and it represents an important health problem in Brazil (9).

This functional incapacity affects both the emotional and physiologic tools of the individuals. This can contribute to many things such as loss of confidence, sadness, bad mood and fear of being inutile. Furthermore, these lasting feeling may lead to depression (10).

This study aimed to estimate the prevalence of lower back pain and to describe the level of functional incapacity in construction workers, all while examining the relationships between: pain and time of service; functional incapacity and pain and level of pain with the functional incapacity.

\section{Methods}

This study was quantitative, transversal and crosssectional in nature (3). It was conducted from May to August 2013 on various construction professionals such as bricklayers, shipowners, carpenters, foreman, mini crane operators and general laborers from a construction company located in Sao Luis. The workers were informed of the study and those who wished to participate signed a TCLE agreement. 
This study was carried out in accords with resolution 196/96 from the National Health Council (11) and the Helsinki Convection (12). The trial was approved by UNICEUMA committee of Ethics and Research number 285.014.

In total, 84 workers participated in this study who had been working for at least 6 months with the company. The study excluded workers who admitted to using pain relievers often.

The data was obtained through three questionnaires that were completed during individual's work time. The first questionnaire was designed to answer demographic variables such as age, profession, civil state, education and ethnicity. Furthermore, other variables were taken into consideration such as smoking, drinking, time at company, hours worked, break time at work, physical exertion, frequency of lower back pain.

The second questionnaire was created by Monnerat and Pereira (13) to measure the intensity of the lower back pain in the individuals. The questionnaire contained 27 questions that assessed the pain intensity through a scale ranging 0 to 4 , along with descriptions of the individual's daily activities. The third questionnaire conducted by Roland-Morris is called functional incapacity. It was translated to Portuguese by Nusbaum et al. (14) and consists of 24 alternatives to daily labor activities that may help ease lower back pain.

The study utilized the program SSPSS 18.0 to analyze the data recorded. For the descriptive analysis, the quantitative asymmetric variables were described in median values, with minimum and maximum values described as frequencies and percentages. This was done in order to measure the relationship between lower back pain and functional incapacity. The Mann Whitney U Test was performed in order to measure the relationship between lower back pain and time of service. Furthermore, the Mann Whitney $\mathrm{U}$ was used again to analyze functional incapacity and pain as asymmetric data with the help of Spearman's lower back pain intensity correlation, with a significancy of $5 \%(P \leq 0,05)$.

\section{Results}

The study included 84 subjects being 83 (98.8\%) male construction workers with the mean age of 32.5 years, minimum of 18 years and maximum of 63 years. In the sample group, 34 (40.5\%) were single and $50(59.5 \%)$ were married. In regards to ethnicity, most workers were brown (77.4\%), followed by black $(15.5 \%)$ and white $(7.1 \%)$. In regards to education level, 50 (59.9\%) had completed fundamental school, $33(39.3 \%)$ had completed high school education and only $1(1.2 \%)$ was illiterate. The highest observed professions observed in the study were carpenters 29 (34.5\%) followed for general laborers 22 (26.2\%) and ship-owners 20 (23.8\%).

The prevalence of lower back pain among the workers was 60 (71.4\%). This pain was more frequent during the course of labor (Figure 1). The mean pain intensity was $4.5(0-32)$ and the functional incapacity was $3(0$ - 19). The scale of functional incapacity by Roland - Morris showed 42 (50\%) of the participants responded the second question and $40(47.6 \%)$ the sixth question.

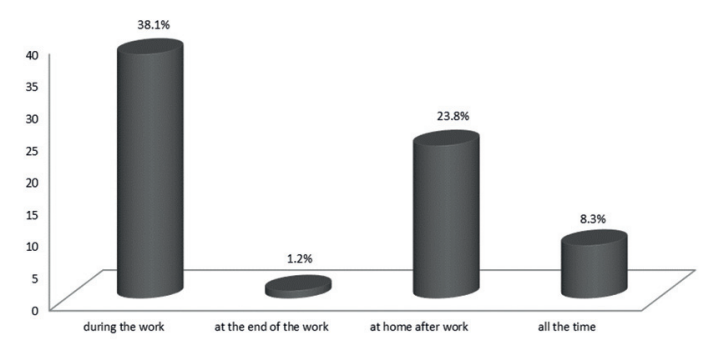

Source: Research data.

Figure 1 - The time of day when the construction workers feel back pain. São Luis - MA, 2013.

All participants performed 8 hours of labor and had a one hour break. Most (91.7\%) reported significant physical exertion. Overall, the workers' time of service was $60(1-480)$ months.

The average, workers' time of service that experienced pain was 60 months (4 - 480) and those who did not, 72 months (1 - 360). The Mann - Whitney $\mathrm{U}$ test was used to analyze the relationship between time of service and pain with a factor of 705 and probability of 0.88 .

The descriptive statistics showed that participants who felt lower back had a lower level of disability (average $=2$ ) compared with participants who did not 
fell pain (average = 6); although, the Mann Whitney U test was 257 with an associated probability of 0.14.

A non-significant negative correlation was found $(\mathrm{r}=-1 . \mathrm{p}=0.15)$ between pain intensity and functional incapacity (Figure 2).

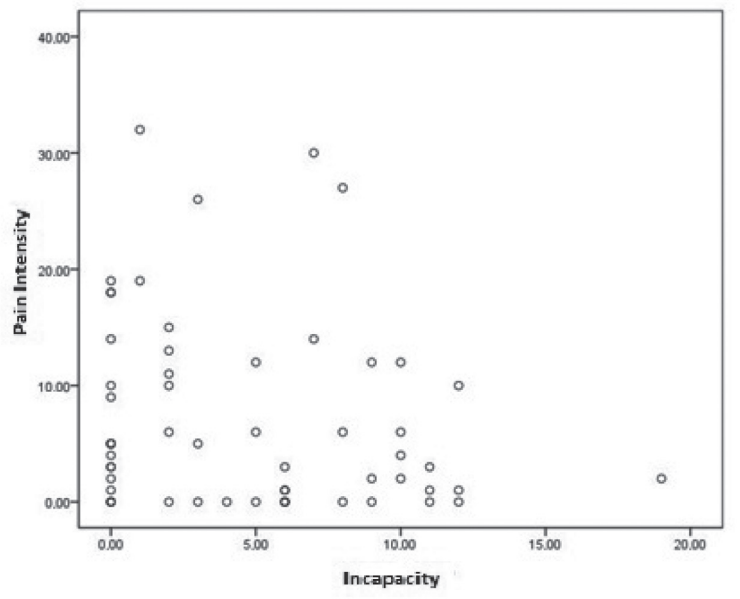

Source: Research data.

Figure 2 - Correlation among pain intensity and functional incapacity in construction workers. São Luis, 2013.

\section{Discussion}

The present study displayed a higher prevalence of lower back pain in construction worker, 71.4\%. Our data was similar to Saad's study (15) accomplished in Ponta Grossa - PR, where $68.13 \%$ of the masons reported pain in some part of the body and $59.67 \%$ being lower back pain.

An international study was similarly conducted in Holland with masons showed $42 \%$ prevalence of individuals with lower back pain which increased to $53 \%$ after 1 year (16). Compared to other similar labor activities $(17,18,19)$ lower back pain presented higher prevalence.

In this present study, lower back pain was more common during laborious activity. Xavier, Michaloski and Saad (20) reported that pain occurred more often due to the rapidly changing positions including twisting, inclining, repetition and lifting.

In contrast with the study by Tsuchiya, Mendonça and Cesar (21) the workers that were interviewed reported pain at the end of their work day because of their work day posture. The extensive laborious activity experienced by the workers puts a heavy strain on the muscles and joints, causing fatigue and pain by the end of the day (22). This study corroborates with the reports given by workers who felt pain at home after a day's work.

The workers interviewed did not show significant levels of functional incapacity at the time of this research, displayed by a median of 3 . Arantes, Nunes and Pernambuco (23) showed similar results, by ranking functional incapacity from 1 - 3. This score was insignificant at determining some types of functional incapacity in workers assessed. Sardá Júnior, Nicholas, Pimenta, Asghari and Thieme (24) observed that people who felt pain and did not stop working because of it, leading to lower mean scores of functional incapacity.

The questionnaire of functional incapacity by Roland - Morris showed that those interviewed responded to the second and sixth questions that referred to the cause of lower back pain as changing positions in order to be comfortable, which in turn cause them to rest more often (14).

An important fact found from this study is that the majority of workers (91.7\%) reported performing significant physical exertion during labor. Batiz, Nunes and Licea (25) found in their study that physical exertion is one of the significant causes of lower back pain in workers. This situation is compounded by the association of physical overload and inadequate postures during laborious activity (26).

Studies have shown $(21,27)$ that weekly work with poor posture adopted in the labor are the most significant factors that cause pain. These factors may explain the reason why present research has showed longer work time does not influence lower back pain in workers.

Moreover in a study performed by Gloria and Gonzalez (28), it was found that all workers who were exposed to lower back pain showed some signs of functional incapacity. Torres, Silva and Xavier (29) reported that workers who had experienced musculoskeletal symptoms in their lower back region had a lower level of functional incapacity in relation to the level of pain in that region.

This study showed that lower back pain did not cause functional incapacity; a fact that may be explained by a slightly lower back pain intensity observed in these workers.

Other studies have shown that lower back pain intensity was correlated to level of incapacity $(7,30$, 31 ). This leads us to conclude that lower back pain is a musculoskeletal symptom that negatively affects a person's ability to perform laborious activity. 


\section{Conclusion}

The data obtained this research showed an explicitly high prevalence of lower back pain in construction workers, while pain intensity remained mild in scale. Furthermore, a close relationship between pain and physical exertion was observed during laborious activity.

In addition, this study did not find a significant level of functional incapacity in workers. Also, time worked did not influence lower back pain, which may just be due to everyday activities.

All research objectives within this study were met and succeeded previous knowledge on this particular topic. This study highlights the need for further research upon musculoskeletal symptoms experienced by construction workers for a better understanding of the problems associated and future mitigation.

\section{References}

1. Matos MG, Hennington EA, Hoefel AL, Dias-da-Costa JS. Dor lombar em usuários de um plano de saúde: prevalência e fatores associados. Cad Saude Publica. 2008;24(9):2115-22.

2. Sá K, Baptista AF, Matos MA, Lessa I. Prevalência de dor crônica e fatores associados na população de Salvador, Bahia. Rev Saude Publica. 2009;43(4): 622-30.

3. Barros SS, Ângelo RCO, Uchôa EPBL. Lombalgia ocupacional e a postura sentada. Rev dor. 2011;12(3):226-30.

4. Plouvier S, Renahy E, Chastang JF, Bonenfant S, Leclerc A. Biomechanical strains and low back disorders: quantifying the effects of the number of years of exposure on various types of pain. Occup Environ Med. 2008;65(4):268-74.

5. Takahashi MABC, Silva RC, Lacorte LEC, Ceverny GCO, Vilela RAG. Precarização do trabalho e risco de acidentes na construção civil: um estudo com base na Análise Coletiva do Trabalho. Saude Soc. 2012;21(4):976-88.

6. Hauser MW, Hauser KCP, Frasson AC, Pilatti LA. A indústria da construção civil - um estudo de caso na cidade de Ponta Grossa/PR da sintomatologia da dor e do desconforto em operários através do diagrama de Corlett - Manenica. FIEP Bulletin. 2010;80.
7. Bento AAC, Paiva ACS, Siqueira FB. Correlação entre incapacidade, dor - Roland Morris, e capacidade funcional - SF-36 em indivíduos com dor lombar crônica não específica. e-Scientia. 2009;2(1).

8. Rosa AFG, Garcia PA, Vedoato T, Campos RG, Lopes MLS. Incidência de LER/DORT em trabalhadores de enfermagem. Acta Sci Health. 2008;30(1):19-25.

9. Abreu ATJBA, Ribeiro CAB. Prevalência de lombalgia em trabalhadores submetidos ao programa de Reabilitação Profissional do Instituto Nacional do Seguro Social (INSS), São Luís, MA. Acta Fisiatr. 2010;17(4):148-52.

10. Neves RF, Nunes MO. Incapacidade, cotidiano e subjetividade: a narrativa dos trabalhadores com LER/ DORT. Interface (Botucatu). 2009;13(30):55-66.

11. Brasil. Ministério da Saúde. Conselho Nacional de Saúde. Diretrizes e normas regulamentadoras sobre pesquisa envolvendo seres humanos. Resolução 196. 1996. Brasília: CNS; 1996.

12. World Medical Association. World Medical Association Declaration of Helsinki: Ethical principles for medical research involving human subjects. 59th ed. Seoul (South Korea): WMA General Assembly; 2008.

13. Monnerat E, Pereira JS. Validação e Confiabilidade de um questionário para lombalgia. Fit Perf J. 2009;8(1):45-8.

14. Nusbaum L, Natour J, Ferraz MB, Goldenberg J. Translation. adaptation and validation of the Roland-Morris questionnaire - Brazil Roland-Morris. Braz J Med Biol Res. 2001;34(2):203-10.

15. Saad VL. Análise ergonômica do trabalho do pedreiro: o assentamento de tijolos [master's thesis]. Ponta Grossa (Brazil): Universidade Tecnológica Federal do Paraná; 2008. Portuguese.

16. Boschman JS, van der Molen HF, Sluiter JK, FringsDresen MHW. Musculoskeletal disorders among construction workers: a one-year follow-up study. BMC Musculoskelet Disord. 2012;13:196.

17. Picoloto D, Silveira E. Prevalência de sintomas osteomusculares e fatores associados em trabalhadores de uma indústria metalúrgica de Canoas - RS. Cien Saude Colet. 2008;13(2):507-16. 
18. Almeida MCV, Cezar-Vaz MR, Soares JFS, Silva MRS. Prevalência de doenças musculoesqueléticas entre trabalhadores portuários avulsos. Rev Lat Am Enfermagem. 2012;20(2):243-50.

19. Xu G, Pang D, Liu F, Pei D, Wang S, Li L. Prevalence of low back pain and associated occupational factors among Chinese coal miners. BMC Public Health. 2012;12:149.

20. Xavier AAP, Michaloski AO, Saad VL. Avaliação da existência de DORT de membros superiores através de testes musculares específicos e relatos de dor em pedreiros na tarefa do assentamento de tijolos. Gestao Industrial. 2009;5(4):115-29.

21. Tsuchiya HZC, Mendonça CSL, Cesar ACG. Associação entre características pessoais. organização do trabalho e presença de dor em funcionários de uma indústria moveleira. Fisioter Pesqui. 2009;16(4):294-8.

22. Alexandrino DFL, Ferreira MEC, Lima CL, Makkai LFC. Proposta de inclusão social e melhoria da qualidade de vida e saúde dos catadores e catadoras de materiais recicláveis de Viçosa - MG através da atividade física. Fit Perf J. 2009;8(2):115-22.

23. Arantes AS, Nunes APRO, Pernambuco AP. Prevalência de lombalgia nos fisioterapeutas atuantes na cidade de Formiga-MG. Conexão Ci R Cient. 2009;4(1).

24. Sardá Jr JJ, Nicholas MK, Pimenta CAM, Asghari A, Thieme AL. Validação dos questionários de incapacidade Roland Moris para dor em geral. Rev Dor. 2010;11(1):28-36.

25. Batiz EC, Nunes JIS, Licea OEA. Prevalência dos sintomas musculoesqueléticos em movimentadores de mercadorias com carga. Prod. 2013;23(1):168-77.

26. Ormelez CR, Ulbricht L. Análise ergonômica do trabalho aplicada a um posto de trabalho com sobrecarga física. Rev Uniandrade. 2010;11(2):69-84.

27. Genz JS, Vilagra JM. Tempo de trabalho e sua relação com dor na operação de trator agrícola. Fiep Bulletin. 2009;79.

28. Glória IPS, Gonzalez TO. Incapacidade por lombalgia em trabalhadores do setor de limpeza da universidade de Mogi das Cruzes. Rev Bras Cienc Saude. 2009;7(22).

29. Torres F, Silva FP, Xavier AAP. Ocorrência de sintoma osteomuscular em trabalhadores da indústria de metalúrgica. Fiep Bulletin. 2013;83.
30. Pedrini TF. Sintomas ostemusculares e a percepção dos trabalhadores sobre as condições do trabalho em uma indústria de papel e celulose [master's thesis]. Campinas (Brazil): Universidade Estadual de Campinas; 2011. Portuguese.

31. Salvetti MG, Pimenta CAM, Braga PE, Corrêa CF. Incapacidade relacionada à dor lombar crônica: prevalência e fatores associados. Rev Esc Enferm USP. 2012;46(Esp):16-23.

Received in $07 / 23 / 2014$

Recebido em 23/07/2014

Approved in 12/03/2015

Aprovado em 03/12/2015 